\begin{tabular}{|c|c|c|c|c|c|c|}
\hline \multirow{4}{*}{ Impact Factor: } & ISRA (India) & $=3.117$ & SIS (USA) & $=0.912$ & ICV (Poland) & $=6.630$ \\
\hline & ISI (Dubai, UAE & $=\mathbf{0 . 8 2 9}$ & РИНЦ (Russia & $=0.156$ & PIF (India) & $=1.940$ \\
\hline & GIF (Australia) & $=0.564$ & ESJI (KZ) & $=8.716$ & IBI (India) & $=4.260$ \\
\hline & JIF & $=1.500$ & SJIF (Morocco & $=5.667$ & OAJI (USA) & $=0.350$ \\
\hline
\end{tabular}

\begin{tabular}{|c|c|}
\hline $\begin{array}{l}\text { SOI: } \underline{1.1 / \mathrm{T}} \\
\text { International Sc} \\
\text { Theoretical } \boldsymbol{\&}\end{array}$ & $\begin{array}{l}\frac{\mathrm{AS}}{\mathrm{D}} \text { DOI: } \frac{10.15863 / \mathrm{TAS}}{\text { cientific Journal }} \\
\text { Applied Science }\end{array}$ \\
\hline p-ISSN: 2308-4944 (print) & e-ISSN: 2409-0085 (online) \\
\hline Year: 2019 & Volume: 70 \\
\hline Published: 28.02 .2019 & http://T-Science.org \\
\hline
\end{tabular}

SECTION 13. Geography. History. Oceanology. Meteorology.
QR - Issue

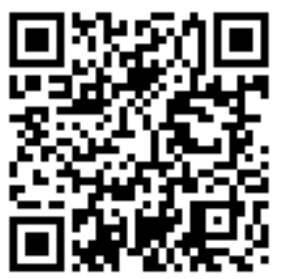

QR - Article

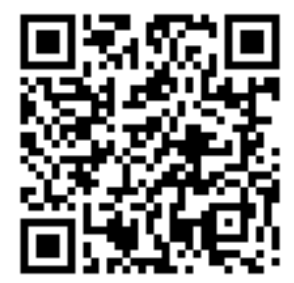

Shahnoza Alisherovna Kasimova senior teacher

National Institute of Arts and Design named after Kamoliddin Behzod jasur184@list.ru

\title{
THE YOUTH ARE SUCH AS REALLY AND POTENTIAL AUDITORY IN THE ART MUSEUM
}

Abstract: This article demonstrates the issues of innovative approach in museum pedagogy, especially communication "museum and education" and its importance to the role in improving the quality of teaching.

Key words: museum, school, education, pedagogy, innovation, exhibit, exposition.

Language: English

Citation: Kasimova, S. A. (2019). The youth are such as really and potential auditory in the Art museum. ISJ Theoretical \& Applied Science, 02 (70), 268-273.

Soi: http://s-o-i.org/1.1/TAS-02-70-25 Doi: crossef https://dx.doi.org/10.15863/TAS.2019.02.70.25

\section{МОЛОДЕЖЬ КАК РЕАЛЬНАЯ И ПОТЕНЦИАЛЬНАЯ АУДИТОРИЯ ХУДОЖЕСТВЕННЫХ МУЗЕЕВ}

Аннотация: В данной статье освещень вопросы инновационного подхода в музейном педагогике, 8 частности связи “музей и образования” и его значение роли в повышении качество обучения.

Ключевые слова: музей, икола, образования, педагогика, инновация, экспонат, экспозиция.

\section{Introduction}

At present, the importance of culture and art in the education of young people is of great importance, in this sense museums play an important role. Today museums, as social and cultural institutions, play a huge role in the spiritual development of the nation. Aware of their important educational and educational significance, the leadership of the republic adopted a number of fundamental documents aimed at improving the museum business in the country.

"We must never forget one truth: without the development of culture and art in our country, society will not progress. The level of development of our people will be assessed primarily on the basis of national culture. Therefore, culture is the image of our people, society. Once we have begun to create a new image of Uzbekistan, we must begin this work with the development of national culture".

\section{Materials and Methods}

The dynamic development of high technologies, the growing challenges of globalization, the consistent integration of our country into the world economy set us the task of consistently raising the level and quality of training young personnel and their legal culture, strengthening the ideological immunity, creating even more favorable conditions for realizing potential. This in turn dictates the need to further improve the legal foundations of the state youth policy.

In the changing historical and social conditions, museums, while continuing to be the custodians of cultural heritage, are undergoing a serious transformation, turning into a system that is increasingly open to society, focused on meeting its needs with its collections and research. Much attention is paid to the development of new forms of the museum with a youth audience and to attracting the attention of young people to the historical and cultural heritage. Contacts have been established with active and interested children's and youth associations. Thus, we can conclude that youth programs in museums of Uzbekistan are available, there are also ways to attract young people, which are developed both by the museum staff and by the young people themselves who are interested in developing their personality and continuing the traditions of visiting museums.

It is culture that makes the people a nation, contributes to the spiritual and moral education of 


\begin{tabular}{|c|c|c|c|c|c|c|}
\hline \multirow{4}{*}{ Impact Factor: } & ISRA (India) & $=3.117$ & SIS (USA) & $=0.912$ & ICV (Poland) & $=6.630$ \\
\hline & ISI (Dubai, UAE & $=0.829$ & РИНЦ (Russia) & $=0.156$ & PIF (India) & $=1.940$ \\
\hline & GIF (Australia) & $=0.564$ & ESJI (KZ) & $=5.015$ & IBI (India) & $=4.260$ \\
\hline & JIF & $=1.500$ & SJIF (Morocco) & $=5.667$ & OAJI (USA) & $=0.350$ \\
\hline
\end{tabular}

youth, education in the spirit of love for the Motherland, its great past and traditions. Considering culture not only as a cultural heritage, but also in a culture where young people know and appreciate art as a whole. In modern conditions, it is of particular importance to appeal to the cultural heritage of the past, the spiritual experience accumulated by mankind over many centuries of national and world history. Not only in philosophy and cultural studies, but also in everyday practice, today there is a search for guidelines that determine the vector of development of Uzbekistan and the world in the new century. That is why nowadays museums acquire such high significance as guardians of the values of the past, in a new way attracting young people, on whose shoulders in the near future will be responsible for the fate and Uzbekistan of all humanity.

Under present conditions, museums are acquired as centers of culture, enriching young people with knowledge of the past, contributing to the development of their value consciousness and spiritual maturity. Contradictions of modern history change the content of the needs and demands of students, create special obstacles in their search for new ideals and moral guidelines. Studying the changing interests and needs of students in modern conditions is an urgent task today, largely determining the ability of educational and educational institutions to have a positive impact on the formation of a new generation of citizens of Uzbekistan. Of particular importance is the solution of these tasks for museums and museum staff involved in the work to broaden their horizons and raise the level of culture of students. The solution of these issues is no less important for university professors who have the opportunity to organically include various forms of interaction with museums in the course of organizing the educational process. The joint efforts of museums and higher educational institutions to develop and deepen the culture of students is one of the most important elements in the preparation of a spiritually mature, well-educated and highly cultural shift, the new generation of Uzbekistan in the 21st century.

A large role is played by art and aesthetic education in the formation of morality. Even Aristotle wrote that music is capable of influencing the aesthetic side of the soul, and since it possesses such a property, it should be included in the number of subjects for the education of young people. Art develops the aesthetic culture of a person, teaches him to understand the beautiful and to build, as already noted, life according to the "laws of beauty".

The shift in emphasis of the value system from the spiritual component to the material one led to the formation of a culture of consumer attitude towards everything surrounding them among young people, including university students. In this regard, it becomes relevant to identify the educational opportunities of a higher education institution of culture in the formation of the spiritual component of a student's value system and, on this basis, to develop a methodology for forming the spiritual component of a student's value system. You can try to solve the problem with the help of art as a carrier of the value paradigm - a significant component of the spiritual world of each person. The justification of this approach is explained by the daily involvement of university students of culture in the framework of educational practice in the process of perception and creation of an artistic and creative product by means of art.

The concept of art in the works of researchers is a way of understanding reality, which is revealed in the process of communication between the author of a work of art (as a result of art) and its perceivers, which ensures the transfer of sensory experience and the existence of social consciousness. Art is part of the spiritual culture of man, which has great educational value. The realization of the educational potential of art in relation to young people, in our opinion, will be possible provided that the younger generation has a valuable attitude to art.

Museum tours, lectures, classes and holidays acquaint children and teenagers with the history of their homeland, its ethnic composition, natural and geographical zones, show people's life, various types of dwellings, clothing, traditional crafts and types of folk art. During the excursions and classes used modern methods of museum pedagogy. Involving young visitors in active work, "immersing" them in the atmosphere of the past, museum programs contribute to the formation of ethnic identity, historical thinking and museum culture. Many excursions and activities for children and adolescents are based on the content of school programs and complement training courses in history, geography, literature and local history, and recreational programs can make the leisure of children and adults more interesting and informative.

The youth audience requires special attention from the museum, which has significant potential to assist young people in finding the meaning of life and the grounds for identification, overcoming crisis situations, in nurturing sensitivity, receptivity and at the same time developing sustainable life guidelines, facilitating adaptation in conditions of social instability. At the same time, the urgent need for interaction with the museum, declared by the youth, remains unmet because it is not supported by their real behavior, appeal to the museums, which creates the need for a deep and comprehensive analysis of the attitude of young people to museums, most pronounced in the motives of their visitation, distribution of interests audiences between specific museums, in the ideas of young people about this 


\begin{tabular}{|c|c|c|c|c|c|c|}
\hline \multirow{4}{*}{ Impact Factor: } & ISRA (India) & $=3.117$ & SIS (USA) & $=0.912$ & ICV (Poland) & $=6.630$ \\
\hline & ISI (Dubai, UAE & $=0.829$ & РИНЦ (Russia) & $=0.156$ & PIF (India) & $=1.940$ \\
\hline & GIF (Australia) & $=0.564$ & ESJI (KZ) & $=5.015$ & IBI (India) & $=4.260$ \\
\hline & JIF & $=1.500$ & SJIF (Morocco) & $=5.667$ & OAJI (USA) & $=0.350$ \\
\hline
\end{tabular}

cultural institution and those aspects and components of its activity that have the greatest appeal.

In the years of independence in our country, the development of the sphere of culture and art, the construction of relevant modern institutions on the basis of advanced international experience, the strengthening of their material and technical base, and the state's comprehensive support for the creative intelligentsia are given priority attention.

A large-scale work was carried out aimed at raising the cultural level of the population, especially the younger generation, familiarizing with the best examples of national and world culture, educating on this basis spiritually mature, harmoniously developed personalities, realizing the abilities and potential of talented youth.

In the modern world, scientists divide the museum audience into real and potential: "It is customary to distinguish between people who visit a museum at a given time (the real audience of a museum) and all those people who can potentially become its visitors (potential auditorium). Many museums conduct visitor research, focusing on the real audience. However, in cases where the task is to increase attendance or attract a new audience, or simply keep your visitor in an increasingly competitive environment, attention can be focused on the potential audience. The potential audience is usually too heterogeneous in composition to work with it, as with a single, homogeneous group, whether in the field of exhibitions, advertising or customer service.

To a greater extent, the museum contributes to enriching the life experience of young people, their spiritual improvement and harmonization of the inner world, while participants in an expert survey believe that young people are least inclined to be guided by this motive, turning to museums.

The paramount properties of the museum collection, attracting an audience of the younger generation, museum workers consider the wealth and content of the collection. The main factor, called upon to attract the audience of the younger generation, is the specific properties of the information broadcast by the museum, since this is where they see an opportunity to demonstrate all the advantages and richness of the museum collection.

In modern conditions, when there are significant changes in the socio-demographic composition of the younger generation, the system of its value orientations, the need-motivational sphere and the conditions of its socialization and self-realization, the effective implementation of museum-pedagogical activity is possible under the condition of constant correlation approaches, principles, forms and methods of working with the requirements of the needs of this audience, and this also provides for constant thorough testing and the clarification of the initial ideas about the most volatile in both structural and value-orientation-oriented social groups of museum visitors.

The twenty-first century is a time of strong development of information technologies that have become an integral part of the life of the young generation. Due to this, many of them have fallen and may fall under the influence of spiritual and global threats. Therefore, today, attracting the younger generation to museums is an important task for museum staff. Because, through different art and youth exhibitions, young people have an interest in beauty and love for traditions, history and the future of their people and their native country.

A museum in modern society is not only a scientific and educational institution, but also a center of culture that solves the tasks of developing and educating a person. The museum, museum exhibits have a unique opportunity to influence the intellectual, volitional and emotional areas of the adolescent's personality at the same time, and each exposition is a program for the transfer of knowledge, skills, judgments, evaluations and feelings.

The museum forms in the young citizen a sense of belonging to everything that happens in the surrounding world, the desire to take part in important events taking place in the world, awakens in adolescents a sense of mercy towards elders, war and labor veterans.

Culture is a concept that has a huge number of meanings in different areas of human activity. Generally, culture means human activity in its most diverse manifestations, including all forms and methods of human self-expression and selfknowledge, the accumulation of skills and abilities by man and society in general. Thus, culture is a collection of sustainable forms of human activity, without which it can not be reproduced, and therefore exist.

Hence, the highest manifestation of culture is the spirituality of a person, that is, his moral core. Each person defines his spirituality in his own way, but there is something in it that should be inherent in everyone, without which it cannot simply be. First of all, it is the love of relatives and friends, their Fatherland, its history, traditions and customs of the people. This is the desire to devote his life to high thoughts and actions for the good of his homeland.

At first glance, these two concepts have practically nothing in common. However, as we see, one cannot exist without the other. Thus, patriotism implies pride in one's country, including all activities carried out by its inhabitants or on its territory. Culture, on the other hand, should have a response in the hearts of people, it should be liked first of all by the compatriots of the master. It turns out that culture forms patriotism.

The society cannot live and develop both without science, and without music, fiction, theater, 


\begin{tabular}{|c|c|c|c|c|c|c|}
\hline \multirow{4}{*}{ Impact Factor: } & ISRA (India) & $=3.117$ & SIS (USA) & $=0.912$ & ICV (Poland) & $=6.630$ \\
\hline & ISI (Dubai, UAE & $=0.829$ & РИНЦ (Russia & $=0.156$ & PIF (India) & $=1.940$ \\
\hline & GIF (Australia) & $=0.564$ & ESJI (KZ) & $=\mathbf{5 . 0 1 5}$ & IBI (India) & $=4.260$ \\
\hline & JIF & $=1.500$ & SJIF (Morocco & $=5.667$ & OAJI (USA) & $=0.350$ \\
\hline
\end{tabular}

cinema, painting and other types of art - a true fullblooded culture. The defense of the Fatherland, one of the components of patriotism, is the defense of its culture, all that is created by its people, their faith, traditions and customs.

In our understanding, culture is not only metropolitan performances, exhibitions and museums. No Western trends, which are advocated by modernity, no theories about universal human values will not replace the identity of national culture, mutually enriched culture of peoples living together for hundreds of years with the concepts of a single state, with common goals.

In order to attract the attention of the younger generation, it is necessary to apply new methods in museum practice, with the help of which visiting a museum can be an exciting and exciting journey. All that is needed for this is a mobile gadget with Internet access and the presence of a special program, an augmented reality browser. The essence of such technology of augmented reality, or ARtechnology (Augmented Reality), designed to increase the attendance of museums and interest in them, is to impose virtual reality on objects of the real world.

It should be noted that in practice our museums use different technologies. For example, in cooperation with UNESCO, the State Museum of Art of Uzbekistan applies the concept of information technology in museum activities.

The State Museum of Art of Uzbekistan is a cultural, educational and scientific institution. This is the first art museum, which was organized in Central Asia. Founded in 1918 in Tashkent as a museum of the National University, since 1935 has the current name.

The museum has over 70 thousand exhibits, the annual number of visitors exceeds 250 thousand people. The Museum has the sections "Folk Applied Arts of Uzbekistan", "Fine Arts of Uzbekistan", "Russian Art", "Art of Western Europe" and "Art of the Foreign East", as well as a repository, a restoration workshop, a photo lab, and a lecture hall. The museum conducts research work in the field of visual and applied art, both in Uzbekistan and abroad, on the basis of scientific research publishes catalogs and albums, organizes thematic exhibitions.

To expand the interest of young people in the State Museum of Art of Uzbekistan, it is proposed to apply non-traditional ways to attract young people.

It should be noted that art exhibitions play a significant role in educating the young generation. For this reason, in order to acquaint young people with the creative works of artists and artisans, various exhibitions are annually held that awaken a sense of patriotism and love for the traditions of their native country.

The state youth policy of Uzbekistan is aimed at raising a harmoniously developed young generation - physically healthy and spiritually mature, intellectually rich, possessing not only versatile knowledge, but also able to independently think, look boldly into the future and able to take responsibility for the fate of our Motherland.

The state youth policy in the law is defined as a system of socio-economic, organizational and legal measures carried out by the state and providing for the creation of conditions for the social formation and development of the intellectual and creative potential of young people.

Another component of the spirituality, morality and culture of the individual is a religious belief. Since ancient times, religions embody much spiritual and moral values. The peculiarities of the lifestyle of nations are reflected in the peculiarities of the religions they profess. At the same time, the main religions of the world are based on the same ideas, rely on such human virtues as kindness, peacefulness, mercy, cry for honesty and purity of soul, generosity.

"May God be in your soul, and hands in labor" ("Dealing - Allohda, kuling - mechnatda bullsin") this is the wise saying of Bahouddin Naqshband for all of us is one of the fundamental life principles.

For our country, where representatives of more than 130 nations and nationalities live, ideas of interethnic harmony and tolerance have a moral meaning, for they are the basis of mutual respect, friendship and cooperation, which, in turn, helps to create an environment of peace and harmony in society, accelerates the path to the cherished goals of people professing different religions and living on the same land, having the same homeland. Whereas nationalism, chauvinism, religious intolerance is a source of interethnic and interfaith conflicts.

In addition, if society in its development comes to the establishment of interaction between secular and religious ideas, in this case the evolution of society can achieve a high level. A good example of this can be the epochs when such great thinkers as Imam Bukhari and Muso Khorezmi, Imam Maturidi and Abu Rayhan Beruni and Ibn Sino, Imam Termizi and Abu Nasr Farobi, who left an indelible mark on human history, lived and worked.

Thus, the concept of "culture", as well as the concept of "patriotism", embraces a whole system of values, norms, products of material production, characteristic of this society and at the same time being an eternal value for all of humanity as a whole.

The modern world is a world of complex contradictions, where the struggle for the consciousness of millions of people is becoming ever more relevant and multifaceted. In order to prevent the spread of immoral ideas that can have a detrimental effect on the spirituality of the people, to stop all attempts to falsify our history, national values and the essence of religion, it is necessary to form public immunity to various kinds of mass 


\begin{tabular}{|c|c|c|c|c|c|c|}
\hline \multirow{4}{*}{ Impact Factor: } & ISRA (India) & $=3.117$ & SIS (USA) & $=0.912$ & ICV (Poland) & $=6.630$ \\
\hline & ISI (Dubai, UAE & $=0.829$ & РИНЦ (Russia & $=0.156$ & PIF (India) & $=1.940$ \\
\hline & GIF (Australia) & $=0.564$ & ESJI (KZ) & $=\mathbf{5 . 0 1 5}$ & IBI (India) & $=4.260$ \\
\hline & JIF & $=1.500$ & SJIF (Morocco & $=5.667$ & OAJI (USA) & $=0.350$ \\
\hline
\end{tabular}

culture products undermining the credibility of genuine culture. A special role in this is given to the mass media, which is an effective means of quickly covering the life of our society, our achievements, difficulties and problems. The media should provide a broad platform to the representatives of the world of culture and art, promoting high moral ideals, moral stability, spirituality, patriotism and vigilance.

There are important factors that increase the interest of young people in museums:

promotion of a museum through the Internet: creating and actively updating the site, creating blogs and communities in social networks and actively interacting with the external environment through these pages;

- attracting investors to the creation and development of Internet museums with a focus not only on creating a network of Russian museums on the Internet, but also on popularizing and attracting young people to their own museum for "continuing the tour" in reality;

- it is necessary to open youth exhibitions (possibly small ones) more often, hold special events and events, have additional ways to attract young people (for example, a small cafe can be opened at the museum), because young people spend a significant amount of free time on meetings and walks with friends, going to cafes, etc. The purpose of the museum is to become a meeting place or, for example, an additional object of a walk;

- ways of further development should be connected with the concept of a "living" museum. The youth would like to see in the museum not "layers of dust on the shelves", but interactive elements, for which it is necessary to move from the principle of closeness of the museum to the principle of complicity. It is desirable that each visitor had the right to leave his mark on the museum's exposition, and not only in the guest book (although the latter is also important);

- it is desirable to pay special attention to attracting schoolchildren to participate in the annual project "Night at the Museum". The survey shows that schoolchildren are less susceptible to this event than students; - museums can support schools and universities in order to create and develop school / university museums: as the survey results show, more than half of the respondents would be interested in such museums. As a result of such activities, museums could manifest themselves outside their own organization;

- a 21 st century museum should have and use a more modern technical base;

- More young people should be involved in museums. Most likely, for this you need to solve the financial problems facing the museums. It is worth paying special attention to the fact that the implementation of the proposed recommendations, subject to their systematic application, will lead to a serious increase in the social benefits of museums and the effectiveness of their functioning.

Thus, the question of the social benefits of the museum for young people remains problematic. On the one hand, young people are aware of the educational function of the museum, which makes it possible to consider this institution as a means of developing human potential. On the other hand, the museum for her is not a significant means of meeting leisure needs. However, in both cases, the youth calls on the museum to change in order to increase its influence in the area of human potential formation.

\section{Conclusion}

Culture is a concept that has a huge number of meanings in different areas of human activity. Generally, culture means human activity in its most diverse manifestations, including all forms and methods of human self-expression and selfknowledge, the accumulation of skills and abilities by man and society in general. Thus, culture is a collection of sustainable forms of human activity, without which it cannot be reproduced, and therefore exist.

Hence, the highest manifestation of culture is the spirituality of a person, that is, his moral core. Each person defines his spirituality in his own way, but there is something in it that should be inherent in everyone, without which it cannot simply be. First of all, it is the love of relatives and friends, their Fatherland, its history, traditions and customs of the people. This is the desire to devote his life to high thoughts and actions for the good of his homeland.

References:

1. Kagan, M. S. (1966). Poznanie $i$ otsenka $v$ iskusstve. Problema tsennosti v filosofii. (pp.98113). M.-L.: Nauka.

2. Vazhenina, S. S. (n.d.). Rol' iskusstva v vospitanii studentov VUZa kul'tury.
«Tyumenskaya gosudarstvennaya akademiya kul'tury, iskusstv i sotsial'nykh tekhnologiy», RF, g. Tyumen' E-mail: vazheninasvetlana@rambler.ru. 


\begin{tabular}{|c|c|c|c|c|c|c|}
\hline \multirow{4}{*}{ Impact Factor: } & ISRA (India) & $=3.117$ & SIS (USA) & $=0.912$ & ICV (Poland) & $=6.630$ \\
\hline & ISI (Dubai, UAE & $=0.829$ & РИНЦ (Russia & $=0.156$ & PIF (India) & $=1.940$ \\
\hline & GIF (Australia) & $=0.564$ & ESJI (KZ) & $=\mathbf{5 . 0 1 5}$ & IBI (India) & $=4.260$ \\
\hline & JIF & $=1.500$ & SJIF (Morocco & $=5.667$ & OAJI (USA) & $=0.350$ \\
\hline
\end{tabular}

3. Yureneva, T. Y. (2003). Muzeevedenie: Uchebnik dlya vysshey shkoly. (p.560). M.: Akademicheskiy prospekt.

4. Solov'ev, V. S. (n.d.). Obshchiy smysl iskusstva. [Elektronnyy resurs]. Retrieved 2019, from http://www.vehi.net/soloviev/smysl_isk.html

5. Chuvilova, I. (2001). «Muzei obshchestva i obshchestvo v muzee» [Elektronnyy resurs]. Retrieved 2019, from http://www.cultivate.ru/mag/issue1/visitor.asp Sotsiologiya molodezhi: ucheb. posobie. In Yu.G. Volkova (Eds.). (p.44). Rostov n/D: Feniks.
6. (n.d.). Retrieved 2019, from http://www.nravstvennost.info/library/news

7. Lukashcheva, T. Y. (2007). Credstvo formirovaniya dukhovnykh tsennostey uchashchikhsya. Nachal'naya shkola, №2, 133140.

8. Stolyarov, B. A. (2004). Muzeynaya pedagogika:Istoriya, teoriya, praktika. ucheb.posobie. (p.216). Moscow: Vyssh. shk.

9. Ariarskiy, M. (1999). Muzey kak institut vovlecheniya cheloveka $v$ mir kul'tury. Muzei Rossii: poiski, issledovaniya, opyt raboty.

10. Demidov, K. (1998). Muzei segodnya: problemқ̧ i perspektivy. Ekaterinburg. 